\title{
Pelatihan Menulis Deskripsi dengan menggunakan Media Gambar untuk Menumbuhkan Nilai-Nilai Karakter
}

\author{
Writing Description Training using Image Media to Grow Character Values \\ Prasetyo Yuli Kurniawan*1, Laelia Nurpratiwiningsih ${ }^{2}$, Tutut Rahayu ${ }^{3}$, Nurul Fitri \\ Ulwiyah $^{4}$, Erni Daryati ${ }^{5}$, M. Wildan Arvin Hakim ${ }^{6}$, Veby Franciska Yuliandini ${ }^{7}$ \\ 1, 3, 4, 5, 6, 7 Program Studi Pendidikan Bahasa dan Sastra Indonesia, Fakultas Keguruan dan Ilmu \\ Pendidikan, Universitas Muhadi Setiabudi, Indonesia \\ ${ }^{2}$ Program Studi Pendidikan Guru Sekolah Dasar, Fakultas Keguruan dan Ilmu Pendidikan,, Universitas \\ Muhadi Setiabudi, Indonesia \\ e-mail: *1prasetyoyulikurniawan@gmail.com, ${ }^{2}$ laelia.np89@gmail.com, ${ }^{3}$ tututrahayu1100@gmail.com, \\ ${ }^{4}$ nurulfitri8@gmail.com, ${ }^{5}$ ernidaryati4@gmail.com, ${ }^{6}$ anjaykomikawal@gmail.com, \\ 7venbyfranciska2019@gmail.com
}

\begin{abstract}
Abstrak
TPA manba'ul Huda desa Siasem merupakan salah satu pendidikan non formal yang ada di kabupaten Brebes. TPA tersebut memiliki jumlah peserta didik yang lumayan banyak mulai dari TK sampai dengan tingkat SD. Namun melihat fenomena yang dilakukan dengan observasi pada TPA tersebut, peserta didik belum mampu mendeskripsikan sesuatu baik dalam wujud benda atau apapun. Dapat dikatakan bahwa peserta didik belum memahami penulisan deskripsi dan mempraktikannya. Selain itu, perlu peningkatan nilai-nilai karakter karena pada masa sekarang era milineal hampir kehilangan nilai-nilai karakter khususnya pada peserta didik. Oleh karena itu, perlu pelatihan penulisan deskripsi yang menuntun mereka memperoleh nilai-nilai karakter. Tujuan kegiatan ini yaitu untuk memberikan pemahaman tentang menulis deskripsi dan memberikan keterampilan peserta didik dalam menulis deskripsi. Selain itu juga untuk memberikan nilai-nilai karakter yang terkandung dalam materi. Metode yang digunakan ada beberapa tahap yaitu metode ceramah, metode latihan, dan metode penugasan. Hasil yang diperoleh kegiatan ini yaitu meningkatnya pemahaman peserta didik dengan nilai prosentasi yaitu 70,40\%. Selain itu, nilai karakter yang muncul dalam peserta didik yaitu nilai religius, jujur, disiplin, demokratis, rasa ingin tahu, bersahabat/komunikatif, peduli sosial, dan tanggungjawab.
\end{abstract}

Kata kunci: Menulis Deskripsi, Media Gambar, Nilai-Nilai Karakter

\begin{abstract}
TPA manba'ul Huda siasem village is one of the non-formal education in Brebes district. It has a fairly large number of learners ranging from kindergarten to elementary level. But looking at the phenomenon done by observation at the landfill, students have not been able to describe something either in the form of objects or anything. It can be said that the learners do not yet understand the writing of the description and practice it. In addition, it is necessary to increase character values because in this day and age the milineal era almost loses character values, especially in learners. Therefore, it is necessary to have description writing training that leads them to acquire character values. The purpose of this activity is to provide an understanding of writing descriptions and give learners skills in writing descriptions. In addition, it is also to provide the character values contained in the material. The methods used are several stages, namely lecture methods, training methods, and assignment methods. The result of this activity is increasing the understanding of learners with a percentage value of $70.40 \%$. In addition, the character values that appear in learners are religious values, honesty, discipline, democratic, curiosity, friendship / communicative, social care, and responsibility.
\end{abstract}

Keyword: Writing Descriptions, Image Media, Character Values

\section{PENDAHULUAN}

Keterampilan berbahasa dipelajari setiap jenjang pendidikan. Mulai dari jenjang taman kanak-kanak, sekolah dasar, sekolah menengah pertama/atas, dan sampai pada jenjang 
perguruan tinggi. Keterampilan berbahasa terdiri atas berbagai aspek yaitu keterampilan menulis, membaca, menyimak, dan berbicara. Dalam hal ini, keterampilan menulis menjadi perhatian karena rendahnya kemampuan menulis siswa dari berbagai jenjang. Keterampilan menulis khususnya menulis deskripsi juga menjadi perhatian. Hal tersebut berakibat yaitu peserta didik sulit untuk mengembangkan paragraph (Idris et al., 2014). Sulitnya peserta didik juga mengalami kendala-kendala yang dialami ketika pembelajaran keterampilan menulis deskripsi berlangsung. Kendala-kendala tersebut yaitu kejelasan tulisan, pengungkapan ide atau pokok pikiran dan organisasi ide yang belum sistematis (Godvany et al., 2017). Melihat fenomena-fenomena tersebut, pada akhirnya nilai keterampilan menulis peserta didik dalam taraf menulis rendah (Ermaneli, 2018).

Rendahnya keterampilan menulis peserta didik harus menjadi acuan bagi guru atau pendidik untuk mengatasi hal tersebut. Baik dari pendidikan formal mapun non formal. Pembelajaran harus menggunakan media yang efektif dan efesien. Media yang dapat digunakan dan dapat ditemui dengan mudah yaitu media gambar. Media gambar menjadi salah satu media pembelajaran dalam keterampilan menulis(Nurjanah et al., 2019). Media gambar bnayak digunakan oleh pendidik untuk pembelajaran. Misalnya lukisan, potret, majalah, dan sebagainya. Dengan memanfaatkan media gambar, peserta didik dapat terbantu dengan gagasan abstrak yang terbentuk secara realistis (Syahrudin, 2010). Melalui media gambar ini, diharapkan mampu meningkatkan kemampuan peserta didik khususnya dalam menulis karangan deskripsi (Zaenudin, 2014).

Dalam melaksanakan pembelajaran menulis deskripsi, peserta didik perlu diberikan nilainilai karakter. Nilai-nilai karakter diimplementasikan melalui pembelajaran Bahasa Indonesia khususnya pada materi menulis deskripsi. Pengintegrasian nilai-nilai tersebut akan memberikan andil kepada peserta didik dalam bertindak tutur dan memegang nilai-nilai yang ada pada budaya kita(Hidayah, 2015). Dalam pengintegrasian tersebut dapat dilakukan berbagai cara. Salah satunya yaitu dengan media pembelajaran yang menarik, melalui materi, dan lain sebagainya. Pengintegrasian ini juga dapat melalui permainan congkak yang dapat menumbuhkan nilai-nilai karakter (Agusti et al., 2018)

TPA Manba'ul Huda merupakan lembaga pendidikan Alquran yang terletak di desa Siasem Kecamatan Wanasari Brebes. Lembaga Pendidikan tersebut. TPA Manba'ul Huda yang dipimpin oleh Arifudin Munaseh sekaligus ustad di desa tersebut telah memiliki peserta didik yang lumayan banyak. Mulai dari tingkat TK sampai dengan tingkat Sekolah Dasar.

Berdasarkan observasi yang telah dilakukan di TPA Manba'ul Huda desa Siasem, peserta didik belum mampu mendeskripsikan sesuatu benda atau hal. Pendeskripsian tersebut dapat berupa lisan maupun tulisan. Jika dalam penulisan peserta didik sudah mampu, maka dalam lisan pun pasti peserta didik mampu. Dengan fenomena tersebut bisa disimpulkan bahwa sampai saat ini peserta didik harus menguasai penulisan deskripsi dalam suatu hal ataupun benda. Khususnya pada peserta didik di TPA Manba'ul Huda desa Siasem. Salah satu contoh yaitu dalam mendeskripsikan suatu gambaar atau suatu fenomena. Dengan demikian maka pengetahuan peserta didik akan meningkat. Fenomena yang lain ditemukan pada peserta didik yaitu rendahnya nilai-nilai karakter anak pada masa sekarang. Nilai-nilai karakter peserta didik perlu dibina agar kelak mereka menjadi manusia yang berakhlak mulia. Melalui menulis deksprisi dengan media gambar diharapkan menumbuhkan karakter peserta didik khususnya di TPA Manba’ul Huda.

Berdasarkan permasalahan yang ada di TPA Manba'ul Huda desa Siasem, maka perlu dilaksanakan kegiatan pengabdian yaitu tentang "Pelatihan Menulis Deskripsi dengan menggunakan Media Gambar untuk Menumbuhkan Nilai-Nilai Karakter.

Tujuan dilakukan pengabdian masyarakat ini yaitu sebagai berikut.

a. Untuk memberikan pemahaman kepada peserta didik TPA Manba'ul Huda desa Siasem tentang teori menulis deskripsi.

b. Untuk memberikan keterampilan menulis deskripsi dengan menggunakan media gambarkepada peserta didik TPA Manbaul Huda desa Siasem.

c. Untuk menumbukan nilai-nilai karakter peserta didik TPA Manbaul Huda desa Siasem. 
Dalam rangka mengatasi permasalahan peserta didik di TPA Manba'ul Huda desa Siasem ditawarkan beberapa solusi yaitu sebagai berikut.

a. Memberikan materi tentang teori-teori menulis deskripsi kepada peserta didik.

b. Memberikan pelatihan menulis deskripsi melalui media gambar untuk menumbuhkan nilai-nilai karakter peserta didik di TPA Manba'ul Huda.

c. Mengintegrasikan nilai-nilai karakter dalam materi dan penugasan yang dirangkum secara komprehensif.

\section{METODE PELAKSANAAN}

Pada metode pelaksanaan pengabdian masyarakat terdapat beberapa pembahasan diantaranya yaitu sasaran pengabdian masyarakat, Tahapan, dan proses pengabdian masyarakat. Hal tersebut dapat dijelaskan sebagai berikut.

\section{Sasaran Pengabdian Masyarakat}

Khalayak sasaran pengabdian ini yaitu peserta didik TPA Manba'ul Huda desa Siasem. Khalayak tersebut berdasarkan karakteristik peserta didik yang masih berada di sekolah TK maupun Sekolah Dasar. Hal tersebut disesuaikan dengan materi yang akan diberikan dalam pelatihan.

Pelaksanaan pengabdian ini melibatkan beberapa pihak. Pihak tersebut meliputi Kepala TPA Manba'ul Huda dan masyarakat sekitar sebagai orangtua yang akan menyukseskan kegiatan pengabdian berupa pelatihan menulis deskripsi.

\section{Tahapan Pelaksanaan Pengabdian Masyarakat}

Permasalahan yang ada pada TPA Manba'ul Huda yaitu masih kurang memahami teori menulis deskripsi dan mempraktikkannya. Permasalahan tersebut dapat diselesaikan dengan beberapa tahap yaitu sebagai berikut.

a. Tahapan Ceramah

b. Tahapan Pelatihan Menulis

c. Tahapan Penugasan

\section{Proses Pengabdian kepada Masyarakat dan Teknik Analisis}

Dalam proses pengabdian kepada masyarakat dapat diuraikan menjadi tiga yaitu kegiatan awal, kegiatan inti, dan kegiatan akhir. Hal tersebut dapat dijelaskan sebagai berikut.

a. Kegiatan Awal Pengabdian

pada kegiatan awal pengabdian masyarakat, peserta didik TPA Manba'ul Huda diberikan motivasi sebagai stimulus dalam mengikuti pelatihan. Hal tersebut dilakukan untuk kelancaran dan kesuksesan dalam memberikan pelatihan kepada peserta didik. Setelah itu peserta didik diberikan apersepsi tentang deskripsi dengan media gambar misalnya gambar anime atau kartun.

Teknik analisis yang digunakan pada kegiatan awal ini yaitu teknik angket. Teknik angket digunakan untuk mengetahui pemahaman awal peserta didik TPA Manba'ul Huda tentang menulis deskripsi. Dari hasil angket tersebut diperoleh data awal pemahaman yang disajikan dalam table. Hal yang ditanyakan dalam angket tersebut yaitu pengertian menulis deskripsi, ciri-ciri menulis deskripsi, macam-macam menulis deskripsi, Langkah-langkah menulis deskripsi, dan media gambar. Pada kegiatan awal tersebut dapat dilihat pada gambar berikut ini.

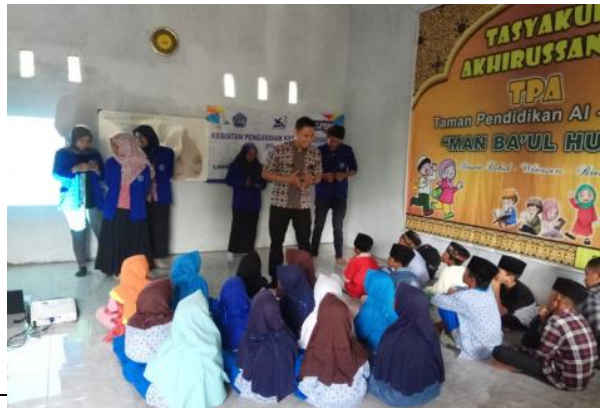


Gambar 1. Pemberian Motivasi, Apersepsi, dan Angket

\section{b. Kegiatan Inti Pengabdian}

Pada kegiatan inti pengabdian masyarakat, peserta didik TPA Manba'ul Huda diberikan materi tentang menulis deskripsi dengan metode ceramah. Kemudian peserta didik diberikan pelatihan menulis deskripsi dengan media gambar yang sudah disiapkan. Setelah peserta didik diberikan materi dan diberikan pelatihan, peserta didik diberikan penugasan sebagai akhir dari evaluasi dari pelatihan ini.

Teknik analisis yang digunakan pada kegiatan inti yaitu teknik angket dan observasi. Teknik angket digunakan untuk mengetahui pemahaman akhir peserta didik TPA Manba'ul Huda tentang menulis deskripsi. Sama dengan pemahaman awal bahwa yang ditanyakan dalam angket tersebut yaitu pengertian menulis deskripsi, ciri-ciri menulis deskripsi, macam-macam menulis deskripsi, Langkah-langkah menulis deskripsi, dan media gambar. Sedangkan teknik observasi digunakan untuk mengamati nilai-nilai karakter yang muncul Ketika proses pelatihan dan penugasan. Pada kegiatan inti dapat dilihat pada gambar berikut

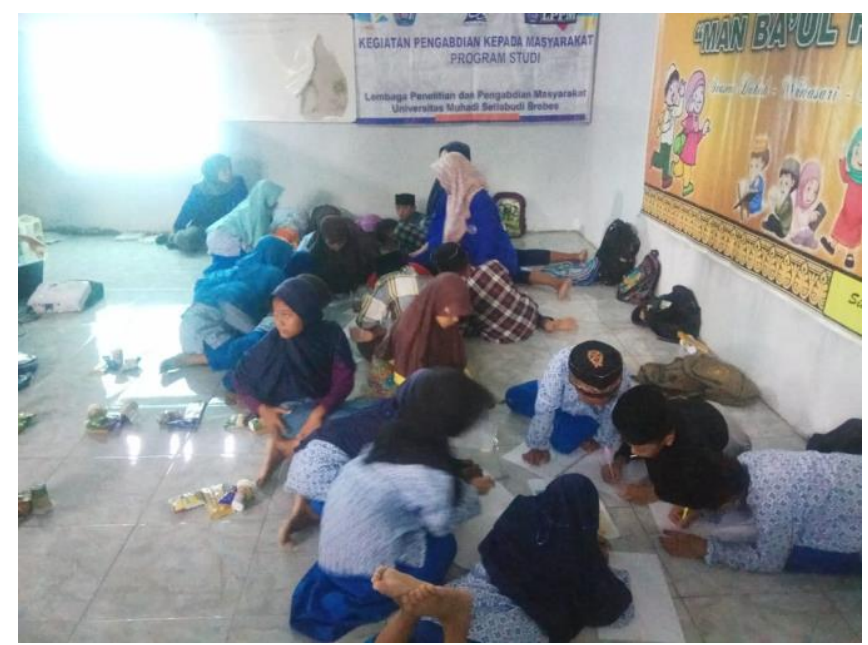

Gambar 2. Pemberian Pelatihan, Penugasan, dan Observasi

\section{HASIL DAN PEMBAHASAN}

Hasil kegiatan pengabdian kepada masyarakat ini berupa penerapan media gambar dalam menulis deskripsi untuk menumbuhkan nilai-nilai karakter. Kegiatan ini dilakukan di TPA Manba'ul Huda desa Siasem Dukuh. Bagian pertama yaitu pemahaman awal peserta didik tentang menulis deskripsi, kemudian bagian kedua pemahaman akhir dan keterampilan peserta didik dalam menulis deskripsi. Kemudian bagian yang akhir yaitu nilai-nilai karakter yang didapat oleh peserta didik.

\section{Pemahaman Awal Peserta Didik TPA Manba'ul Huda}

Pemahaman awal ini dilakukan dengan menggunakan angket yang diberikan kepada peserta didik Manba'ul Huda. Kemudian peserta didik memberikan tanggapan pertanyaan terhadap angket tersebut. Angket tersebut berisi tentang pemahaman menulis deskripsi. Pemahaman tersebut terdiri atas pengertian, ciri-ciri, macam-macam, langkah-langkah, dan media gambar. Pemahaman awal peserta didik dapat disajikan dalam tabel berikut ini.

Tabel 1. Pemahaman Awal Peserta Didik dalam Menulis Deskripsi

\begin{tabular}{ccccc}
\hline No & Aspek & $\begin{array}{c}\text { Jumlah peserta didik } \\
\text { yang memahami }\end{array}$ & $\begin{array}{c}\text { Jumlah total } \\
\text { peserta didik }\end{array}$ & Prosentasi \\
\hline 1 & Pengertian Menulis Deskripsi & 15 & 25 & $60 \%$ \\
\hline 2 & Ciri-ciri Menulis Deskripsi & 10 & 25 & $40 \%$ \\
\hline
\end{tabular}




\begin{tabular}{llcccc}
\hline 3 & $\begin{array}{l}\text { Macam-macam } \\
\text { Deskripsi }\end{array}$ & Menulis & 9 & 25 & $36 \%$ \\
\hline 4 & $\begin{array}{l}\text { Langkah-langkah } \\
\text { deskripsi }\end{array}$ & menulis & 7 & 25 & $28 \%$ \\
\hline 5 & Media Gambar & Nilai rata-rata pemahaman peserta didik & 25 & $52 \%$ \\
\hline & & 13 & $43,20 \%$ \\
\hline
\end{tabular}

Berdasarkan tabel 1. dapat disimpulkan bahwa pemahaman awal peserta didik TPA tentang dalam menulis deskripsi memiliki rata-rata prosentasi $\mathbf{4 3 , 2 0 \%}$. Nilai rata-rata tersebut terdiri atas pengertian menulis deskripsi yaitu 60\%, ciri-ciri menulis deskripsi yaitu 40\%, macammacam menulis deskripsi yaitu 36\%, Langkah-langkah menulis deskripsi $28 \%$, dan media gambar sejumlah $52 \%$.

\section{Pemahaman Akhir dan Keterampilan Peserta Didik TPA Manba'ul Huda}

Sama halnya dengan pemahaman awal, pemahaman akhir juga dilakukan dengan menggunakan angket yang diberikan kepada peserta didik TPA Manba'ul Huda. Namun yang membedakan yaitu angket tersebut diberikan setelah peserta diberikan media gambar dalam menulis deskripsi. Kemudian peserta didik memberikan tanggapan pertanyaan terhadap angket tersebut. Angket tersebut berisi tentang pemahaman menulis deskripsi. Pemahaman tersebut terdiri atas pengertian, ciri, macam, langkah, dan media gambar. Pemahaman akhir peserta didik dapat disajikan dalam tabel berikut ini.

Tabel 2. Pemahaman Akhir Peserta didik tentang Menulis Deskripsi dengan Media Gambar

\begin{tabular}{|c|c|c|c|c|}
\hline No & Aspek & $\begin{array}{c}\text { Jumlah peserta didik } \\
\text { yang memahami }\end{array}$ & $\begin{array}{l}\text { Jumlah total } \\
\text { peserta didik }\end{array}$ & Prosentasi \\
\hline 1 & Pengertian Menulis Deskripsi & 21 & 25 & $84 \%$ \\
\hline 2 & Ciri-ciri Menulis Deskripsi & 19 & 25 & $76 \%$ \\
\hline 3 & $\begin{array}{l}\text { Macam-macam } \\
\text { Deskripsi }\end{array}$ & 15 & 25 & $60 \%$ \\
\hline 4 & $\begin{array}{l}\text { Langkah-langkah } \\
\text { deskripsi }\end{array}$ & 13 & 25 & $52 \%$ \\
\hline 5 & Media Gambar & 20 & 25 & $80 \%$ \\
\hline \multicolumn{4}{|c|}{ Nilai rata-rata pemahaman peserta didik } & $\mathbf{7 0 , 4 0 \%}$ \\
\hline
\end{tabular}

Berdasarkan tabel 2. dapat disimpulkan bahwa pemahaman akhir peserta didik TPA tentang dalam menulis deskripsi memiliki rata-rata prosentasi $\mathbf{7 0 , 4 0 \%}$. Nilai rata-rata tersebut terdiri atas pengertian menulis deskripsi yaitu $84 \%$, ciri-ciri menulis deskripsi yaitu $76 \%$, macam-macam menulis deskripsi yaitu 60\%, Langkah-langkah menulis deskripsi 52\%, dan media gambar sejumlah $80 \%$.

Setelah peserta didik memahami teori tentang menulis deskripsi, peserta didik diberikan pelatihan dan penugasan tentang menulis deskripsi dengan menggunakan gambar. Gambar yang digunakan yaitu gambar kartun atau anime. Kemudian peserta didik menulis deskripsi dari gambar yang sudah diberikan. Hasil dari menulis deskripsi dapat dilihat pada gambar berikut.

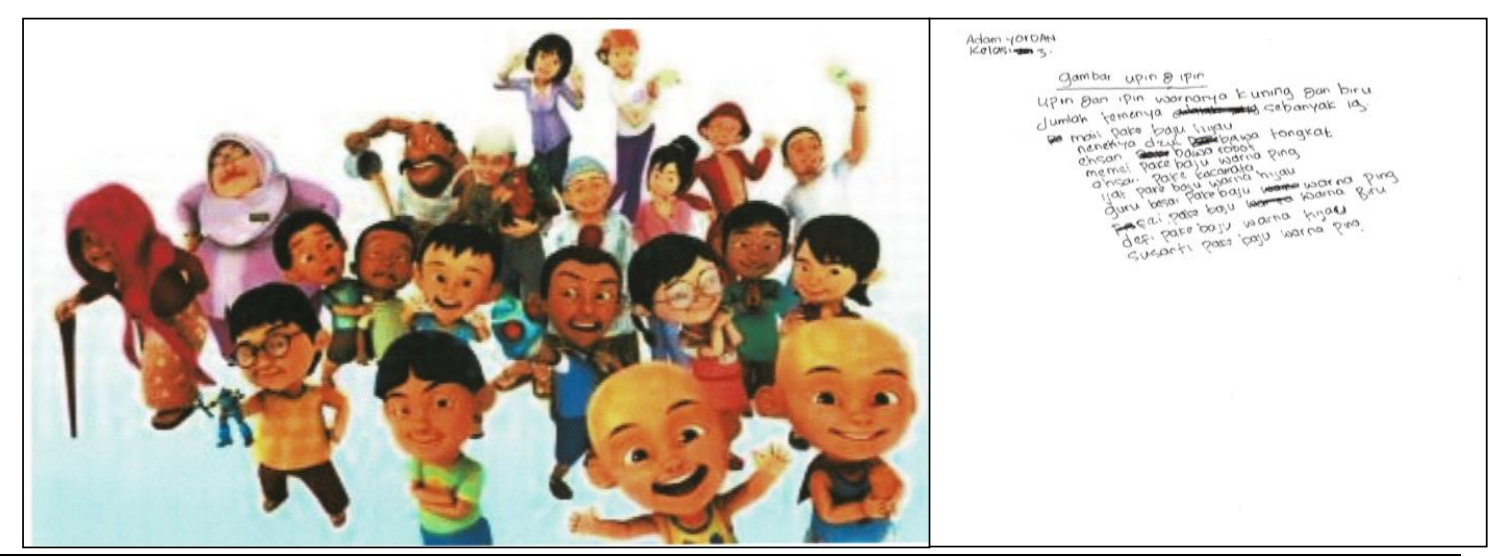

Pelatihan Menulis Deskripsi dengan menggunakan Media Gambar untuk Menumbuhkan NilaiNilai Karakter (Prasetyo Yuli Kurniawan et al) 
Gambar 3. Hasil Keterampilan Menulis Deskripsi

Berdasarkan gambar 3 tersebut, dapat disimpulkan bahwa peserta didik TPA Manba'ul huda memiliki keterampilan dalam menulis deskripsi.

\section{Nilai-Nilai Karakter Peserta Didik TPA Manba'ul Huda}

Nilai-nilai karakter yang diambil dari peserta didik TPA Manba'ul Huda dilakukan dengan menggunakan lembar observasi. Lembar observasi berupa pertanyaan nilai karakter yang muncul dalam proses pembelajaran maupun akhir pembelajaran. Nilai-nilai karakter yang muncul berdasarkan hasil pengamatan observasi yaitu dapat dilihat pada table berikut.

Tabel 3. Nilai- Nilai Karakter Peserta Didik TPA Manba'ul Huda

\begin{tabular}{clc}
\hline \multirow{2}{*}{ No } & Nilai-Nilai Karakter yang Muncul & Prosentase \\
\hline 1 & Religius & $94 \%$ \\
\hline 2 & Jujur & $86 \%$ \\
\hline 3 & Disiplin & $72 \%$ \\
\hline 4 & Demokratis & $75 \%$ \\
\hline 5 & Rasa ingin tahu & $95 \%$ \\
\hline 6 & Bersahabat/komunikatif & $88 \%$ \\
\hline 7 & Peduli Sosial & $83 \%$ \\
\hline 8 & Tanggung jawab & $80 \%$ \\
\hline & \multicolumn{2}{c}{ JUMLAH TOTAL }
\end{tabular}

Berdasarkan tabel 3 dapat disimpulkan bahwa nilai-nilai karakter peserta didik TPA Manba'ul Huda tumbuh dengan prosentasi $84,12 \%$. Nilai karakter terkuat yaitu "rasa ingin tahu" dengan prosentase 95\%. Kemudian nilai karakter yang lemah yaitu "disiplin". Dengan demikian dapat disimpulkan bahwa nilai-nilai karakter peserta didik tumbuh berdasarkan karakteristik peserta didik dalam menghadapi masalah.

\section{KESIMPULAN}

Berdasarkan hasil dan pembahasan pada kegiatan pengabdian masyarakat yaitu "Pelatihan Menulis Deskripsi dengan menggunakan Media Gambar untuk Menumbuhkan NilaiNilai Karakter", dapat disimpulkan bahwa penerapan media gambar dapat meningkatkan pemahaman peserta didik dalam menulis deskripsi. Hal tersebut menunjukan bahwa pemahaman peserta didik awal yaitu 43,20\%. Kemudian pemahaman akhir peserta didik yaitu sejumlah $70,40 \%$. Maka dapat disimpulkan bahwa ada kenaikan $27,20 \%$ dalam pemahaman menulis deskripsi dengan media gambar. Selain itu, peserta didik juga terampil dalam menulis deskripsi dengan menggunakan gambar.

\section{UCAPAN TERIMAKASIH}

Ucapan terima kasih diberikan kepada Kepala TPA Manba'ul Huda dan keluarga dari peserta didik yang secara tidak langsung menyukseskan kegiatan pengabdian ini. Kemudian kepada Rektor Universitas Muhadi Setiabudi melalui kepala LP2M yang memberikan izin untuk melaksanakan pengabdian masyarakat di desa Siasem.

\section{DAFTAR PUSTAKA}

Agusti, F. A., Anwar, F., Alvi, A. F., \& Ernawati, E. (2018). Penanaman nilai-nilai karakter terhadap peserta didik Melalui permainan congkak sebagai media pembelajaran. Jurnal 
Pendidikan Karakter, 8(1), 95-104. https://doi.org/10.21831/jpk.v8i1.21678

Ermaneli, E. (2018). Peningkatan kemampuan menulis karangan deskripsi dengan menggunakan peta konsep bagi siswa kelas VI SDN 44 Lubuk Anau Kecamatan Bayang. 3(1), 70-77. https://doi.org/https://doi.org/10.29210/02164jpgi0005

Godvany, N., Nurjaya, I. G., Gunatama, G., Pendidikan, J., Indonesia, S., Bahasa, F., \& Ganesha, U. P. (2017). Meningkatkan Keterampilan Menulis Karangan Deskripsi Melalui Kegiatan Belajar Di Luar Kelas Dengan Pendekatan Kontekstual Pada Siswa Kelas VII SMP Negeri 1 Sukasada. E-Journal Universitas Pendidikan Ganesha, 6(1), 1-12. https://doi.org/http://dx.doi.org/10.23887/jjpbs.v6i1.9293

Hidayah, N. (2015). Penanaman Nilai-nilai Karakter dalam Pembelajaran Bahasa Indonesia di Sekolah Dasar. Jurnal Pendidikan Dan Pembelajaran Dasar, 2(2), 190-204. https://doi.org/https://doi.org/10.24042/terampil.v2i2.1291

Idris, Y., Thahar, H. E., \& Juita, N. (2014). Peningkatan Keterampilan Menulis Karangan Deskripsi Melalui Metode Discovery Dengan Menggunakan Media Gambar Mahasiswa prodi Pendidikan Bahasa dan Sastra Indonesia TA 2011/2012 Universitas Ekasakti Padang. JUrnal Bahasa, Sastra Dan Pembelajaran, 2(3).

Nurjanah, L., Sadarmaji, S., \& Permanasari, D. (2019). KEMAMPUAN MENULIS PARAGRAF DESKRIPSI MELALUI MEDIA GAMBAR PADA SISWA KELAS X SEMESTER GENAP SMK TRISAKTI BANDAR LAMPUNG TAHUN PELAJARAN 2018 / 2019. Jurnal Ilmiah Mahasiswa Bahasa Dan Sastra Indonesia, 1(2), 1-7.

Syahrudin, D. (2010). Peranan Media Gambar Dalam Pembelajaran Menulis. Eduhumaniora, 2(1). https://doi.org/https://doi.org/10.17509/eh.v2i1.2746

Zaenudin, T. (2014). Keefektifan Penggunaan Media Gambar Dalam Pembelajaran Mengarang Deskripsi di Sekolah Dasar. Metafora, Jurnal Pembelajaran Bahasa Dan Sastra, 1(1). 